\title{
Resolving the Strategy Paradox Applying the Strategic Flexibility: A Case Study of PT BNI Life Insurance
}

\author{
Endah Widati \\ Universitas Indraprasta, Jakarta
}

ARTICLE INFO

Received: January 30, 2012

Final revision: June 20, 2012

Keywords:

strategic flexibility,

strategy paradox,

basic dynamic capabilities,

absorptive capacity,

ambidextrousness,

continuous morphing,

learning organization,

environmental turbulence.

\section{A B S T R A C T}

Over decades, the business environment has changed dramatically as it has been affected by the changing of environmental needs and demand. The difference level of environmental turbulence characteristics will create new business competitive landscape for all companies in any industries. Environmental turbulence is also marked by dynamics, complexity and unpredictability business environment. In such a situation, a company will be difficult to adapt the environmental changes. In a turbulent environment, a company is demanded to be able to adapt. Many researchers argue that in a turbulent environment, a company is not only demanded for having adaptive ability but also flexible ability either structural, operational or strategic. The fast pace of environmental changes provide managers unpredictable outcomes of their strategic alternative or strategic commitment. This collision of strategic commitment and strategic uncertainty is causing what Raynor (2007) named as the strategy paradox. Every company can be a victim of the strategy paradox if they cannot align their strategy with the environmental changes. Raynor (2007) pointed out that one of the ways to resolve strategy paradox is implementing strategic flexibility in term of ex ante action (proactive actions). One of the industries in Indonesia that also experiences the turbulent environment is insurance industry. This study examines and investigates the strategic flexibility as a way to resolve strategy paradox at PT BNI Life Insurance.

(C) 2012 IRJBS, All rights reserved.
$\mathrm{O}$ ver decades, the business environment has changed dramatically and is affected by the changing environmental factors. Ansoff and Sullivan (1993) argue that the changing environmental turbulence factors, such as complexity of event, familiarity of event, rapidity of change and visibility of future, will result different levels of the environmental turbulence. For example: the environment in turbulence level one is essentially stable because the changes in the four factors are stable and slow than the firm's response. Current condition of the new 
business competitive landscapes shows that environmental turbulence is in level five, whic is full of surprises. In this level, the familiarity of events are discontinuous novel, the rapidity of change are much faster that firm's response and visibility of future are unpredictable surprise (Ansoff and Sullivan, 1993). Furthermore, the characteristics of high environmental turbulence, such as unpredictability, complexity and uncertainty, exist as dynamic environment result that is characterized by high level of dynamism which shows positive and non-linear feedback. It forces the decision makers to work harder to predict changes and prepare their corresponding strategies to compete with their competitors to gain the market share

The strategic planning and strategic changes process in turbulent environment are not as easy as it may seem. It is totally a complex process with the ultimate result of avoiding flawed strategies. In a turbulent environment, no one can plan strategy with accurate predictions. Aaker and Mascarenhas (1984) explained that ideally the future could be predicted with enough confidence to justify resulting action plan needs. But since today's competition landscape is totally different from twenty years ago, it is difficult to create strategies in high velocity dynamic market. Being successful and sustainable in a turbulent and hypercompetitive (D’Aveni, 1995) business environment requires a company to apply fit strategies, have sustainable competitive advantages and the capabilities to adapt with the environmental changes (Combe and Greenley, 2004; Eisenhardt and Martin, 2000; Stieglitz and Heine, 2007; Porter, 1996). It is no only adaptive ability but also flexible, eithe structural, operational and strategic. Rayno (2007) argues that adaptation is viable when the pace of organization change matches the pace of environment changes. If the environment changes more slowly or rapidly but the organization does not gain enough pace with the changes, it show that company's ability to adapt is very limited (Leavy, 2007). It explains that company needs more agility rather than only ability to adapt. The company needs to prepare for all possibilities of the events that might occur in the future.

The strategies created by the executives are mostly based on their beliefs about the future condition. If the future condition turns out to be as well as predicted, it will lead to a success. But if the condition does not turn out as expected or turn out differently from prediction, it will lead into a failure. This situation poses difficulties for the executives to predict the future condition. Unpredictable, uncertain future and pace of environment change will pose many threats and opportunities for the company. Moreover, it also gives unpredictable outcomes of company's strategies. The result of unpredictable and uncertain future in creating and implementing strategy is strategy paradox

Indonesian insurance industry is one industry which also experiences such condition. In Asia, Indonesia, a country with more than 210 million citizens, is the largest potential insurance market after India and China. Best's Review (2000) stated that in year 2000 only $10 \%$ of Indonesian people who have life insurance policy. According detikFinance. com (2008), at the end of 2008 the number of life insurance policyholders only increases about $5 \%$ from year 2000. In other words, the current number of life insurance policyholders is only $15 \%$ of total Indonesian citizens. All the players in Indonesian insurance industry believe that this number has potentially increased year by year. Insurance industry is a subset of financial service industry. It is affected by the external environmental factors such as dynamic structural, technology and regulatory changes. It makes conventional planning process and financial decision-making tools less effective than before (Copeland. Jr et al., 2007). Besides, insurance company carries the risk associated with annuities and insurance policies and assign premiums to be paid for the policies. In order to be able to compensate policyholders for their losses, insurance companies invest the money they receive in premiums, building up a portfolio of financial assets and income producing, which can then be used to pay off any future claims that may be brought. If the future turns out differently than the company has planned, the company might need to mitigate strategic risk and position the organization to exploit other emerging opportunities. To realize the actions, a company should create strategic flexibility by identifying options that can be exercised and developing the capabilities of strategic flexibility.

In current business environmental situation, insurance companies face varieties of challenges to survive in competition such as: capital, product innovation, quality of human resources, how the company handles the cases, etc. PT BNI Life Insurance is one of players in insurance industry which also faces such kinds of challenges. Moreover the competition not only comes from local companies but also foreign companies who joint with local company to serve insurance market in Indonesia. Besides that, the company does not only compete with the same core companies, which is life insurance company, but also competes with the other types of insurance companies such as: general insurance company, re-insurance company and social insurance company. According to Investor Magazine (2008), there are 142 companies totally in this industry that consists of 43 life insurances, 90 general insurances, 4 reinsurances and 5 social insurances companies. In 2009, Investor magazine shows that total companies in this industry increase into 144 companies. The players in insurance industry consist of 46 life insurance, 89 general insurance, 4 reinsurance and 5 social insurance companies. This number represents that the competition in insurance industry is high and tight.

In high-velocity environment, making accurate prediction is something difficult for the management. One-way to face the unpredictable and uncertain situation is to prepare all the possible events that might occur. As mentioned before that the company has to be able to determine the strategy that match with the environment, where the company operates, so the company will have sustainable competitive advantages. The ability of being flexible is not possessed by all companies. Based on the explanation, the aim of this study is to examine the strategic flexibility as a way to resolve strategy paradox in PT BNL Life Insurance. More specifically this study sets the objective such as: (1) To examine how does PT BNI Life Insurance maintain or improve its performance, compete with their competitors and not become one of the victims of strategy paradox in turbulence environment and hypercompetitive market; (2) To explore the capabilities that possessed by PT BNI Life Insurance in facing the turbulence environment and hypercompetitive market; (3) To analyze how PT BNI Life Insurance develops its strategic flexibility capabilities; (4) To investigate how PT BNI Life Insurance assesses its strategic flexibility.

\section{Literature Review}

\section{Strategy Paradox (Based on Reynor, 2007)}

Raynor (2007) defines strategy paradox as the strategies with the greatest possibility to success also have the greatest possibility of failure. He identified that strategy paradox is strategy that is most likely to bring an organization outstanding success but it can also expose the organizatio to spectacular failure. He explained that the bes performing firms often have more in common with bankruptcies than with companies that have managed merely to survive. Additionally he mentioned that determinants of high achievemen are also the ingredients of total collapse. The cause of the strategy paradox is similar as it is unseen. In other words, to notice a strategy paradox, a company has to put it under the microscope strategy whose only flaw was that they flopped. A successful strategy allows an organization to create and capture value. To create and capture value, an organization should consider three main players in formulating strategy business. A mention in the 3'C model of Ohmae or strategic triangle consists of corporation itself, customer 
and competition. The $3 \mathrm{C}$ has a role to create and capture value for the company. To create value, firm must connect with its customers. For a firm to capture value, its strategy must be resistant to imitation by competitors. Satisfying customers in ways competitors cannot copy, requires significan commitment to a particular strategy, known as strategic commitments. It should have unique assets or particular capabilities.

The strategy paradox arises from the collision of commitment and uncertainty. The most successful strategies are those based on commitments made today that are best aligned with tomorrow's circumstances. But no one knows what those circumstances will be, because the future is unpredictable. If the company guessed wrong and committed to the wrong capabilities, it will be impossible to adapt. After all, a commitment tha can be changed was not much of a commitment. As a result, success is very often a result of having made what turned out to be the right commitment (good luck), while failed strategies, which can be similar in many ways to successful ones, are based on what turned out to be the wrong commitment (bad luck). In other word, the strategy paradox is a consequence of the need to commit to a strategy despite the deep uncertainty surrounding the strategy, which the organization committed to.

The Dynamic Nature of The Environment

Environment (businessdictionary.com) is define as circumstances, influences, stresses, and competitive, cultural, demographic, economic natural, political, regulatory, and technological factors (called environmental factors) that effec the survival, the operation, and the growth of an organization. These environmental factors provide opportunities or threat to the business activities. Every company tries to grasp the available opportunities and face the threats that emerge from the business environment. There are two types of environment that are faced by a busines organization. Firstly, the internal environment tha related to their internal business components.
Secondly, the external environment that related with the circumstances around the business exists. The company can environment but they just can react and anticipate for any changes.

Environmental turbulence or turbulence environmental are similar 'terms' used to show characteristics of the high changing in the circumstances. Khadwalla (1977) defines turbulent environment as dynamic, unpredictable, expanding and fluctuating environment (Weerdt, 2009). Volberda (1998) as cited in Weerdt (2009) defines turbulent environment as a complex aggregate of various dimensions such as levels of dynamic, complexity and unpredictability of external change that reflects the degree of change in competitive forces [Porter's five forces] (Porter, 1980). In a turbulent environment, the markets are usually emergent, which is no clear dominant design, no stable business model, no clear boundaries between or within an industry and no clear competition. In other word, Eisenhardt and Martin (2000) argue that high velocity markets are those in which market boundaries are blurred, successful business models are unclear, and market players such buyers, suppliers, competitors and complementers are ambiguous and shifting. Ultimately as a result, a turbulent environment can cause market environment changes faster. The faster changes become the reason for demand fluctuation that is far greater than seasonal cycles (SAP Solution, 2007). Of course, quick responses to the changing market dynamics will mitigate the risk of losing the business to competition.

\section{Organizational Learning-4I Framework}

In a turbulent environment, when changes happen much faster, learning becomes an essential skill in all levels in an organization. Bitar (2003) argues that companies not only react to and anticipate change but also create change continuously. The continuous changing can be done by managing the organization's past and future at the same time in the present and constantly learning and absorbing knowledge from within the organization and the external environment that completely rooted in an ecosystem of collaborators and competitors.

Over 40 years ago, Cyert and March (1963) define organizational learning as a process by which organizationas collectives learn throughinteraction with their environments (cited in Sinkula, 1994). The organization needs organizational learning to face and adapt with environmental changes. It continuously needs to assess its market demand from time to time in order to be able to develop and deliver value to its customers. Despite the fact, the outcome of learning will not be useful to help the organization in order to survive in dynamic market if it is not integrated in existing strategy. In turbulent environment, a company cannot become the victim of strategy paradox if its strategies are aligned with the environments. In other words, the needs of alignment between strategies and environment remain important (Raynor, 2007; Mitzberg et al., 1998 cited in Crossan and Berdrow, 2003). Crossnan et al. (1999) developed the 4I framework that aims to portray the dynamism of organizational learning. This framework shows the alignment between organizational and environments.

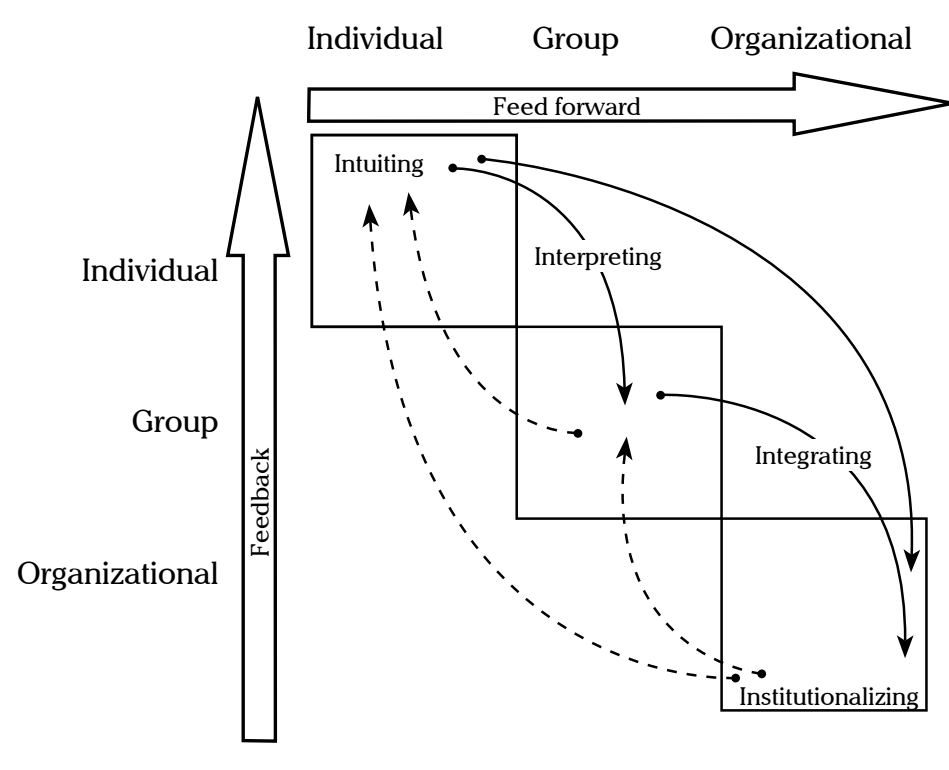

Figure 1. Organizational Learning as a Dynamic Proces Source: Crossan, Lane, and White (1999)
The 4I framework that consists of intuiting interpreting, integrating and institutionalizin serves to link three levels of analysis, which are individual, group and organization, and define learning within organization. Intuiting and interpreting occur at the individual level; interpreting and integrating happen at the group level; and integrating and institutionalizing take place at the organization level (Crossan and Berdrow, 2003). According Figure 1, Crossan et a. (1999) defines the learning process as follows:

1. Intuiting is the preconscious recognition of the pattern and/or possibilities inherent in a persona stream of experience. This process can affec the intuitive individual's behavior, but it only affects others as they attempt to interact with tha individual.

2. Interpreting is the explanation of an insight, or idea to one's self and to others. This process goes from the preverbal to the verbal and requires the development of language.

3. Integrating is the process of developing shared understanding amongst individuals and the taking of coordinated action through mutual adjustment. Dialogue and joint action are crucia to the development of shared understanding. This process will initially be ad hoc and informal, but 
if the coordinated action taking is recurring and significant it will be institutionalized.

4. Institutionalizing is the process of ensuring that routinized actions occur. Tasks are defined, actions specified and organizational mechanism put in place to ensure that certain actions occur. Institutionalizing is the process of embedding learning that has occurred by individuals and groups into the institutions of organization including systems, structures, procedures and strategy.

The arrows seen in Figure 1 depict that 4 framework recognizes that the competitive position of a firm is dynamic not static, with influences working through feedback loops. These feedback loops refer to the process of learning (Crossan et al., 1999).

\section{Competitor Analysis}

In strategy formulation process, it is necessary to know all about the company's competitors, such as their feasible strategic moves, their capabilities, their goals, their current strategy, etc. Competitor analysis aims to develop a profile of the nature and success of the likely strategy changes each competitor might make, each competitor's probable response to the range of feasible strategic moves other firms could initiate and each competitor's probable reaction to the array of industry changes and broade environmental shifts that might occur (Porter, 1980). Sophisticated competitor analysis is needed to answer few important questions such as: (1) Who should our company pick a fight with in the industry and with what sequence of moves? (2) What is the meaning of that competitor's strategic moves and how seriously should the company take it? and (3) What area should our company avoid because the competitor's response wil be emotional and desperate? (Porter, 1980). In fact, sophisticated competitor analysis tends to be ignored by the manager of a firm because of hazardous assumptions. Porter (1980) mentions that the components of competitor analysis are: future goals; assumptions; current strategy and capabilities.

\section{Strategic Flexibility}

Eccless coined the term of "strategic flexibility" in the latest of 1950s (Eccless, 1959 cited in Evans, 1991). It was then he explained that the intellectual concept of strategy naturally leads to the intellectual concept of flexibility. The value of flexibility realized when the effective action is taken to inflict or respond to the changing environment. According to Moltke, strategic flexibility provides the firm or company with the capability to modify its strategies. In the sense of classical and terms of flexibility, Moltke defines strategies as a practical adaptation of the means at one's disposal to achieve the objective in the future (Paret, 1986 cited in Evans, 1991).

The use of the word flexibility is ubiquitous and overlaps with other words such as adaptability, resilience, elasticity, agility and versatility, etc (Stigler, 1939; Evans, 1991). Those words are the conjecture to lead to the concept of flexibility (Evans, 1991). Many scholars, researchers and practitioners, such as Evans (1991), Hart (1937) and Upton (1994), from all disciplines frequently and extensively use the notion of flexibility and define it to show the organization's ability deal with a turbulent environment. In strategic management literature, flexibility viewed as a core principle of business strategy (Evans, 1991; Hart, 1937) that related to a firm's abilities to deal with changing environment circumstances (Harrigan, 1985 cited in Fellenz, 2000). Strategic flexibility is defines as a firm's deliberately crafted ability (MacKinnon et al., 2008) to identify major changes (Shimizu and Hitt, 2004; MacKinnon et al., 2008), to adapt (Aaker et al., 1984), to respond quickly commit resources to various demand (Sanchez, 1995) and new direction of action (Shimizu and Hitt, 2004), to mitigate threats and exploit opportunities (MacKinnon et al., 2008) to substantial, uncertain, and fast occurring environmental changes that have a meaningful impact on the organization's performance (Aaker et al., 1984; Shimizu and Hit, 2004).

Furthermore, Raynor (2007) viewed strategic flexibility as the ability to change strategies, which is something made largely impossible by the commitments required for success. Raynor (2007) also mentioned that the strategic flexibility is very different from run-of-the-mill flexibility of adaptability. In this term, he said that "flexibility" means, "change within existing constraints." As mentioned before adaptability sometimes overlaps with flexibility, but Raynor (2007) emphasizes that adaptability only can help an organization or a company to face uncertainty and unpredictable future if the organization's pace of changing can match with the changing pace of its environment. So if the organization's pace cannot match with the pace of change in environment, it will show the limit of adaptability in its applicability and is far from a sufficient respond. Raynor (2007) mentioned that strategic flexibility consists of two fundamental constructs, such as; scenario-basedplanning and real option. Thus, the company would need an option to impose long-term constrains to create a strategic adaptation

Fellanz (2000) explains that strategic flexibility influenced by the 'real', internal and external condition of the firm and also by the ability of strategic makers to recognize and conceptualize limitations and opportunities inherent in the organization's complex situation, and their ability and willingness to develop action alternatives for the firm. Capabilities are intangible resources or assets, made up of component such as skill, learning and knowledge in deploying tangible or other intangible assets or resources (Combe et al., 2004). The strategic flexibility terms can be applied in two levels (Combe et al., 2004), level of firm and level of decision maker. In the level of firm, strategic flexibility applied to denote the ability of the firm to respond and successively adapt to changing environment. While in level of the decision maker, strategic flexibility applied as an extent to which new and alternative options in strategic decisionmaking are generated and considered to face uncertainty condition. The capabilities owned by the decision marker or company could generate different form of strategic flexibility. Sanchez (1995) explained that concept of strategic flexibility depends together on the inherent flexibilities of the available resources in the firm and flexibilities in applying those resources to alternative course of action

\section{Capabilities of Strategic Flexibility}

Many researchers propose different capabilitie of strategic flexibility (dynamic capabilities) such as: resources flexibility and coordination flexibility (Sanchez, 1995; 1997). While Shimizu and Hitt (2004) identify three capabilities such as: (1) attentions, the capability to pay attention to negative feedback; (2) assessment, the capability to collect and assess negative data objectively; and (3) action, the capability to initiate and complete change in a timely fashion even in the face of uncertainty. Besides that Shimizu and Hitt (2004) add that strategic flexibility also involves cognitive ability to recognize problem and change direction. The capabilities of strategic flexibility also know as dynamic capabilities (Eisenhardt and Martin 2000). Teece et al. (1997) define dynamic capability to integrate, build and reconfigure internal and external competence to address rapidly changing environment. According Bitar (2003), a firm need three generic dynamics capability to generate multiple capabilities or competences in turbulen environment, such as: absorptive capacity, which is defined as an organization's ability to identify external information, recognize its value, assimilate it with existing internal information and use it in a value creation process(Cohe and Levinthal, 1990), ambidextrousness describe as ability to implement both incremental and revolutionary change (Tushman and O'Reilly, 1996) and continuous morphing is described as comprehensive ongoing transformation through which the focal firm sought to regenerate their transient competitive advantages on the industry 
(Rindova and Kotha, 2001). Bitar (2003) argues generic dynamic capabilities seems to be at the very foundation of dynamic capabilities allowing entities to create new information, capture existing information and combine them in learning processes that lead to new capabilities.

\section{Framework of strategic flexibility}

According to Raynor (2007), the framework of strategic flexibility in term of ex ante event define as a framework to identifying uncertainties and developing the option needed to mitigate risk or exploit the opportunities. The strategic flexibility framework proposed by Raynor involves four phases. Those four phases of strategic flexibility can depict on Figure 2.

Anticipate: The first phase is anticipate, it include identify drivers of change, define the range of possible future, and develop scenario.

Formulate: The second phase of strategic flexibility framework proposed by Raynor (2007) is formulate phase. In this phase the organization required to determine the optimal strategy or the best strategy for each scenario. And then compare all the optimal strategies to define the core element and contingent element.
Accumulate: Accumulate phase is the phase to create optimal real options and ensure they remain valuab element of strateg strategy identified, the organization can build or acquire the resources needed for each strategy.

Operate: This is the ultimate phase. In this phase, the organization required to have a close monitoring to the environment, which allow the organization to determine which of its scenario most accurately captures the most important element in the future, which optimal strategy is most appropriate, which contingent element are required and which option should be exercised or abandoned.

\section{METHODS}

This study is an analytical descriptive study using interactive approach (Sugivono, 2011) with BNI Life Insurance as a subject company. In collecting the data, this study uses individual depth interviews and surveys. It is conducted base on structured interview questions and structured questionnaires that distribute to the top management team who is highly involved in company operation and has good understanding of strategic planning process of a company. In analysing the data, this study

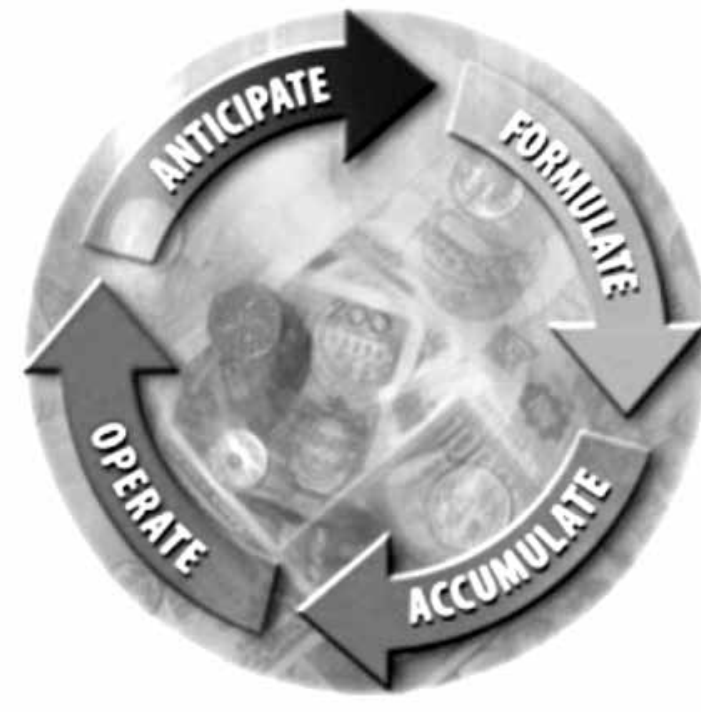

Figure 2. The Framework of Strategic Flexibility

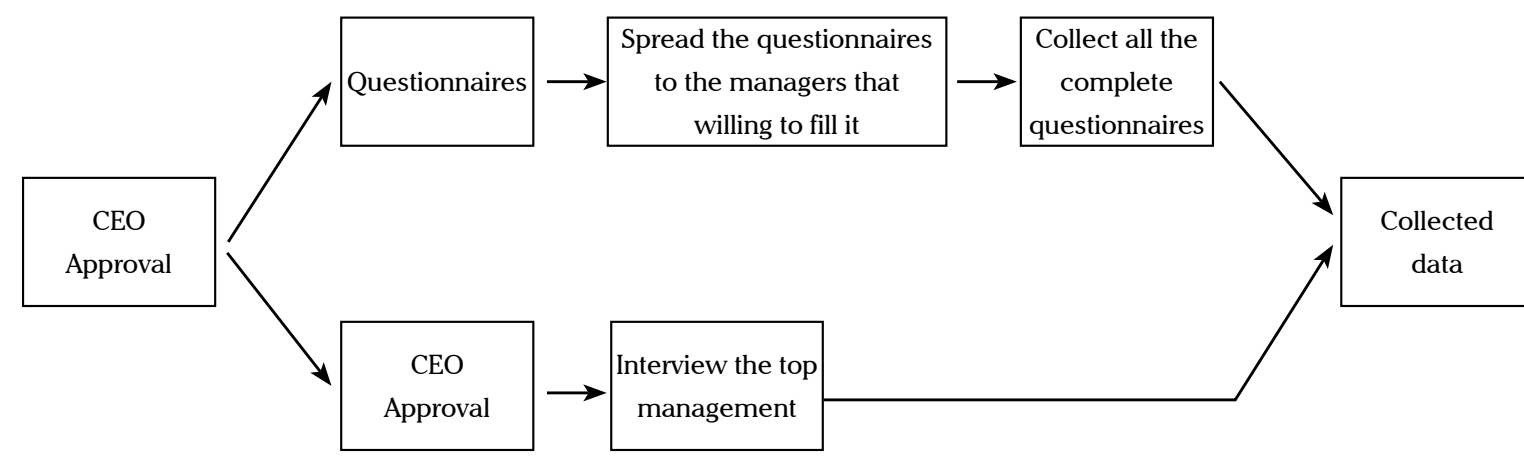

Figure 3. Data Collection Process

use internal analysis based on VRIO framework (Barney, 2002), competitor analysis (Porter, 1980), dimensions of environmental turbulence (Duncan, 1972; Volberda, 1998), strategic flexibility framework (Raynor, 2007) and flexibility audit (Aaker and Mascarenhas, 1984).

\section{Internal Analysis}

two main factors that drive a firm's performance, first the external environment and industry effects (Porter, 1980; Hawawini et al., 2003), second, firm's resources and the strategy being adopted (Rumelt, 1991). According to Barney (1991), resources-based view (RBV) emphasizes the internal capabilities of the organization in formulating strategy to achieve a sustainable competitive advantage in its markets and industries. Daft (1983, cited in Barney, 1991) point out that firm's resources include all assets, capabilities, organizational process, firm attributes, information, knowledge etc. controlled by a firm that enable the firm to conceive of and implement strategies that improve its efficiency and effectiveness

Barney (1991) argued that sustainable competitive advantage develops from the resources and capabilities that have four attributes such as valuable, rare, imperfectly imitable and not substitutable. Barney also pointed out that it is necessary that resources, which are used as a source of sustainable competitive advantage, are heterogeneously distributed and immobile between firms. Based on those attributes, firm's resources should be analyzed with regard to their value, their rarity, their imitability and their exploitation by organization. The VRIO-framework, which is the fundamental of internal analysis, is showed in Figure 5 .

\begin{tabular}{|c|c|c|c|c|c|}
\hline \multicolumn{6}{|c|}{ Is a resource or capability.. } \\
\hline Valuable & Rare? & $\begin{array}{l}\text { Costly to } \\
\text { Imitate }\end{array}$ & $\begin{array}{l}\text { Exploited by } \\
\text { organization }\end{array}$ & $\begin{array}{l}\text { Competitive impli- } \\
\text { cations }\end{array}$ & $\begin{array}{l}\text { Economic } \\
\text { performance }\end{array}$ \\
\hline No & & & No & $\begin{array}{c}\text { Competitive disad- } \\
\text { vantage }\end{array}$ & Below Normal \\
\hline Yes & No & & 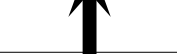 & Competitive parity & Normal \\
\hline Yes & Yes & No & $y$ & $\begin{array}{l}\text { Temporary compe- } \\
\text { titive advantage }\end{array}$ & Above Normal \\
\hline Yes & Yes & Yes & Yes & $\begin{array}{l}\text { Sustained competi- } \\
\text { tive advantage }\end{array}$ & Above Normal \\
\hline
\end{tabular}
Source: Barney (2002) 
Valuable. A resource is valuable if it helps the organization meet an external threat or exploit an opportunity. The resources that lead to competitive advantages are only the resources give valueadded to organization. Whereas, the non-valueadding capabilities may lead to competitive disadvantage.

Rarity. A firm enjoys a competitive advantage when it is implementing a value-creating strategy not simultaneously implemented by large numbers of other firms. If the particular bundles of firm resources are valuable but not rare or common, it will lead to competitive parity but no advantage. While valuable and rare resources and capabilities have the potential to provide temporary competitive advantage

Imitability. Valuable and rare resources and capabilities can be a source of competitive advantage only if the competitors that do no possess those resource and capabilities canno obtain them and have difficult time to imitate them It is ease to imitate the tangible resources such as plants and equipments, while it is a lot more challenging to imitate the intagible capabilitie such as tacit knowledge and managerial talents. Firm resources can be imperfectly imitable fo one or a combination of three reasons: (1) the ability of a firm to obtain a resource is dependen upon unique historical conditions; (2) the link between the resources possessed by a firm and firm's sustained competitive advantage is causally ambiguous; (3) the resource generating firm's advantage is socially complex.

Organization. Firm resources and capabilities cannot give a firm sustained competitive advantage, if it is not properly organized. That is, even it valuable, rare and hard-to-imitate. But it is rarely are firms not organized to exploit their valuable resources and capabilities. In some case, a firm is unable to take full advantage of those resource and capabilities because sometimes their firm is not organized to do so and sometimes the firm is designed to exploit different strengths of its resources and capabilities.

In order to get the confirmation or answers to analyze the target company's resources and capabilities, this study categorized the resources and capabilities as shown as following.

Thus, the questions proposed to evaluate the target company's resources and capabilities are

a. Financial resources

b. Physical resources

c. Human resources

d. Organizational capabilities

e. Learning or know-how capabilities

f. Brand Loyalty

g. Contract or relationship

Network externalitie

Geographic location

Thus, the questions proposed to evaluate the target company's resources and capabilities are

Value. Do the resources or capabilities enable the organization to exploit an opportunity or neutralize a threat?

Rarity. How many competing firms possess this resource of capability?

Imperfectly Imitable. Can (will) the competitors obtain the same of similar resources?

Organization. Can (will) the competitors obtain the same of similar resources?

\section{Competitor Analysis}

As mention before, that in strategy formulation process, it is necessary to know all about company's competitors. Based on the competitor analysis framework, there are four factors such as future goals, current strategy, assumptions and capabilities. In order to develop the competitor's response profile of target company, this study uses structured questioner with yes/no answer model. Each factor will consist of 3-16 questions. For example, to examine the company's knowledge about future goals of its competitors, the questionnaire consists of 16 questions and additional detail assessment of competitor's future goals based on its main competitors. The detail assessment of competitor's future goals consist of 6 points of interest, such as state or unstated financial goals of the competitor, the competitor's attitude toward to risks, competitor's organization value or belief, competitor's organization structure, competitor's control and incentive system and competitor's generic strategic.

Thus, in order to examine the competitor's assumptions, this study propose 10 questions and 4 point to assess the detail information about competitor's assumption. Furthermore, to assess the competitor's strategy, this study only uses detail assessment with 3 point of interest such as the strength of competitor's strategy, weakness of competitor's strategy and the competitor's current strategy. To explore the competitor's capabilities, this study proposes 9 questions.

\section{Environmental Turbulence}

According to Volberda (1998), the dimensions of environmental turbulence consist of complexity, dynamic and unpredictability. Complexity is defined as the number of factors taken into consideration in making decision (Duncan, 1972). Duncan (1972) describes dynamism as the level of stability of those environmental factors. Furthermore, unpredictability reflects the extent to which cause effect relationships concerning competitive forces are incomplete (Volberda, 1998).

In order to develop environmental turbulence profile of the industry, this study uses assumption based on the answer of respondents about the environmental turbulence perceptions. The questionnaire consists of three dimensions and each dimension consists of $4-5$ questions. Similar with other questionnaires in this study, the environmental turbulence perception questionnaire is also in the form of yes/no questions. The environmental turbulence perception will be measured using scores such as, Yes $=1$ and No $=0$ for dynamic and complexity dimension. Different scoring system will be applied to unpredictability dimension that is $\mathrm{No}=1$ and Yes $=0$ and reverse questions $(*)$, which is applying reverse scoring.

\section{Strategic Flexibility}

This study uses strategic flexibility framework (Raynor, 2007) and flexibility audit (Aaker and Mascarenhas, 1984) to assess the effectiveness of strategic flexibility and to examine the strategic flexibility in term of strategic planning possessed by the target company. Aaker and Mascarenhas (1984) explained that each variable of flexibility audit is related to the functional area such as research and development, finance, operations, marketing, international, managerial/structure. To avoid biased result of the assessment, the flexibility audits, which are objective and subjective assessment, are distributed to high-level manager of corporate company as parent company of targe company. In order to determine whether strategic flexibility is efficient or not, it will be compared with the industry.

\section{RESULTS AND DISCUSSION}

Nowadays, companies are operating in highly uncertain and facing a combination of heightene macro-economic, demand, competitive an capital market risks. New dogma mentioned that in dynamics market and fast technology change rivals can quickly copy any market position and at best the competitive advantage become temporary (Porter 1996). In this turbulent environment, companie must be flexible to respond rapidly to competitive and market changes. For coping with such kind of the uncertain environment, companies need to implement the different way of strategic thinking and maintain few core competencies in the race to stay ahead of competitors. Porter (1996) also add that companies must benchmark continuously to achieve best practice and aggressively to gain efficiencies. 
In turbulence environment, a company must be having many questions related to its business activity, the questions such as: (1) how can the company compete in turbulence environment? (2) Can the company maintain its performance? (3) What should the company do to maintain its performance? (4) Isitbeing commit orbeing flexible to face the turbulence environment and take the advantage of uncertainty? (4) Is the company's strategy aligned with the environment condition? etc. As mentioned before, these questions only can answer when company apply different way of strategic thinking. Beside the different way of strategic thinking, a company should also see its resources and capability to answer the questions. This study aims to evaluate and investigate the capabilities proposed by BNI Life in order to maintain and improve its performance in turbulen environment. Based on those aims Figure 6 shows the summary of this study finding.

As seen in the figure, the business environment, which BNI Life exists, is dynamics, complex an controllable. The dynamic dimension is depicted by the very intense of changing in the life insurance industry, i.e, the changing of regulation and competition between the companies in the industry. Based on research, the life insurance industry possesses very high level of complexity, it depicts that each of environmental factors in its busines environment will affect the company's decisions. While the unpredictable condition faced by life insurance companies is mostly related with the customers demand, competition, capital marke condition, regulation and the nature of environmental condition. Overall, BNI Life's environmen turbulence profile shows that BNI Life faces big threat and also opportunities because of high dynamic and complexity (see Figure 7) . These conditions will give big impact both negative and positive impact to BNI Life's business activities and its strategy to compete with its competitors.

In the business environment that such faced by BNI Life, BNI Life should be flexible in term of strategic decisions without ignoring its strategic commitment, or in other words BNI Life should have flexible commitment. BNI Life should examine its strategy and its resources and capabilities to face the environmental turbulence. Based on the research, this study finds few of BNI Life's resources and capabilities still in the temporary and parity of competitive nature. As shown in Table 1, it is only loyalty brand that have sustainable competitive advantage nature. Besides loyalty brand, it shows that BNI Life does not have resources and capabilities that can give them the competitive advantage. Compared to its peer competitors, BNI Life performance is still above the normal. But if we compare with the others competitors in the industry, BNI life is still far to reach its positioning as market leader.

BNI Life applies differentiation strategy as its generic strategy. The similar strategy also applied by most of the insurance companies. Porter (1980) explained that being different means company creates something that is perceived industry wide as being unique. He mentioned that being different, it requires company to have resources and skills such as: strong marketing abilities, product engineering, creative flair, strong capability in basic research, corporate reputation for quality or technological leadership, long tradition in the industry or unique combination of skills drawn from other businesses and strong cooperation from channels.

These things are truly realized by Mrs. Lilies Handayani, as a CEO of BNI Life Insurance. Along with her team, since 2008 BNI Life has made many changes in its organization such as in marketing, products, services and its operational. For example: in marketing, BNI Life tries to reach middle-up as a target market. Through new product such as Spectra Link, BNI Life tries to make its unit link product become perfect unit link product. Beside that BNI Life also implement the "independent sales office" to increase numbers of its networks and areas that BNI Life wants to serve. BNILife

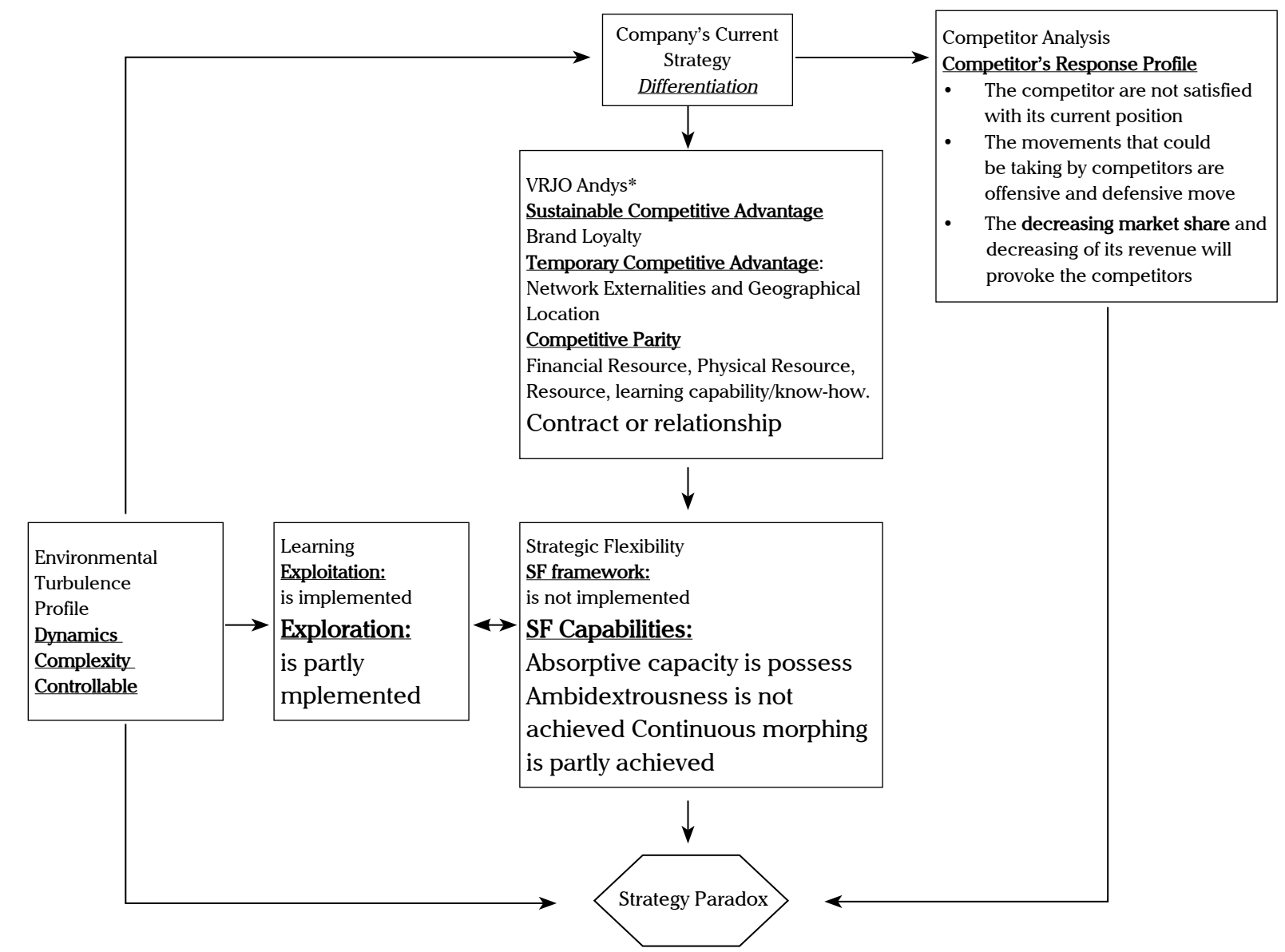

Figure 6.The Summaries of Findings

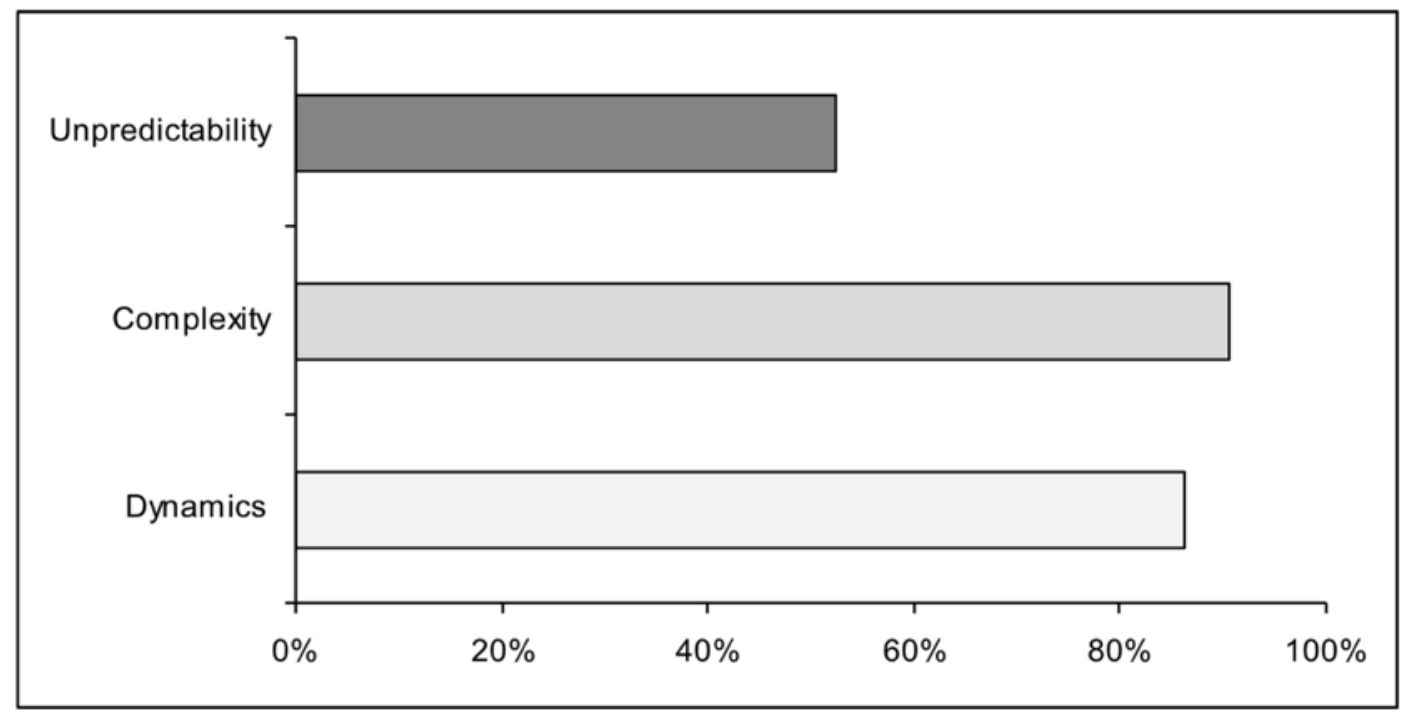

Figure 7. Environmental Turbulence Profile of BNI Life Insurance Source: Data Process 
Table 1. BNI Life's Internal Analysis - VRIO Framework

\begin{tabular}{|c|c|c|c|c|c|c|}
\hline $\begin{array}{c}\text { Resources \& } \\
\text { Capabilities } \\
\end{array}$ & Valuable? & Rare? & $\begin{array}{l}\text { Costly to } \\
\text { Imitate? }\end{array}$ & $\begin{array}{l}\text { Exploited by } \\
\text { organization? }\end{array}$ & Competitive Implication & $\begin{array}{c}\text { Economics } \\
\text { Performance } \\
\end{array}$ \\
\hline $\begin{array}{l}\text { Financial } \\
\text { Resources }\end{array}$ & Yes & No & No & Yes & Competitive parity & Normal \\
\hline $\begin{array}{l}\text { Physical } \\
\text { Resources }\end{array}$ & Yes & No & No & Yes & Competitive parity & Normal \\
\hline $\begin{array}{l}\text { Human } \\
\text { Resources }\end{array}$ & Yes & No & No & Yes & Competitive parity & Normal \\
\hline $\begin{array}{l}\text { Organizational } \\
\text { Capabilities }\end{array}$ & Yes & No & No & Yes & Competitive parity & Normal \\
\hline $\begin{array}{l}\text { Learning } \\
\text { Capability / } \\
\text { Know-how }\end{array}$ & Yes & No & No & Yes & Competitive parity & Normal \\
\hline Brand Loyalty & Yes & Yes & Yes & Yes & $\begin{array}{c}\text { Sustainable competitive } \\
\text { advantage }\end{array}$ & Above normal \\
\hline $\begin{array}{l}\text { Contract or } \\
\text { Relationship }\end{array}$ & Yes & No & No & Yes & Competitive parity & Normal \\
\hline $\begin{array}{l}\text { Network } \\
\text { Externalities }\end{array}$ & Yes & Yes & No & Yes & $\begin{array}{l}\text { Temporary competitive } \\
\text { advantage }\end{array}$ & Above normal \\
\hline Geographical & Yes & Yes & No & Yes & $\begin{array}{l}\text { Temporary competitive } \\
\text { advantage }\end{array}$ & Above normal \\
\hline
\end{tabular}

hires new people in charge in agency division to improve its agencies performance.

Besides possessing the resources and capabilitie with competitive advantage nature, a company needs implement a unique strategy to gain its market share and face the dynamics and uncertain market. In nowadays business environment, where the uncertainty and complexity exist, a company should have capability to adapt and configure its capability and resources, in order to survive and win the competition. These abilities will helps a company mitigate its risks and avoid itself not become a strategy paradox victim. One strategy to avoid the company becomes strategy paradox victim is strategic flexibility. In order to separate the process of strategic flexibility implementation, this study divide it into 2 categorizes such as proactive (ex ante) and reactive actions (ex post).

Seen from its strategic planning process (see Figure 7), this study find that currently BNI Life insurance has not implement the strategy flexibility framework in term of ex ante or proactive action. But BNI Life insurance already applies the strategic flexibility in term of ex post or reactive action. The changing in strategy occurs when the treat of achieving goals exist, which is can be caused by uncontrollable changing, becomes portray of BNI Life's ability in modify its strategy.

According to Shimizu and Hitt (2004), it is not easy for a company to possess the strategic flexibility capabilities. Even though there are many barriers such as complacent mind-set (decision rules including hubris), organizational inertia, self-justification, framing effects, organizational politics, perceived uncertainty regarding the prospect of the project and resistance to change. It does not mean a company cannot possess these capabilities, Bitar (2003) argues that a company can possess the strategic flexibility capability as long as they possesses three basic or generic dynamics capabilities, such as: absorptive capacity (Coven and Levinthal, 1990), ambidextrousness (Tushman and O'Reilly, 1996) and continuous morphing (Rindova and Kotha, 2001).

Coven and Levintal (1990) explained that companies' absorptive capacity can be generated

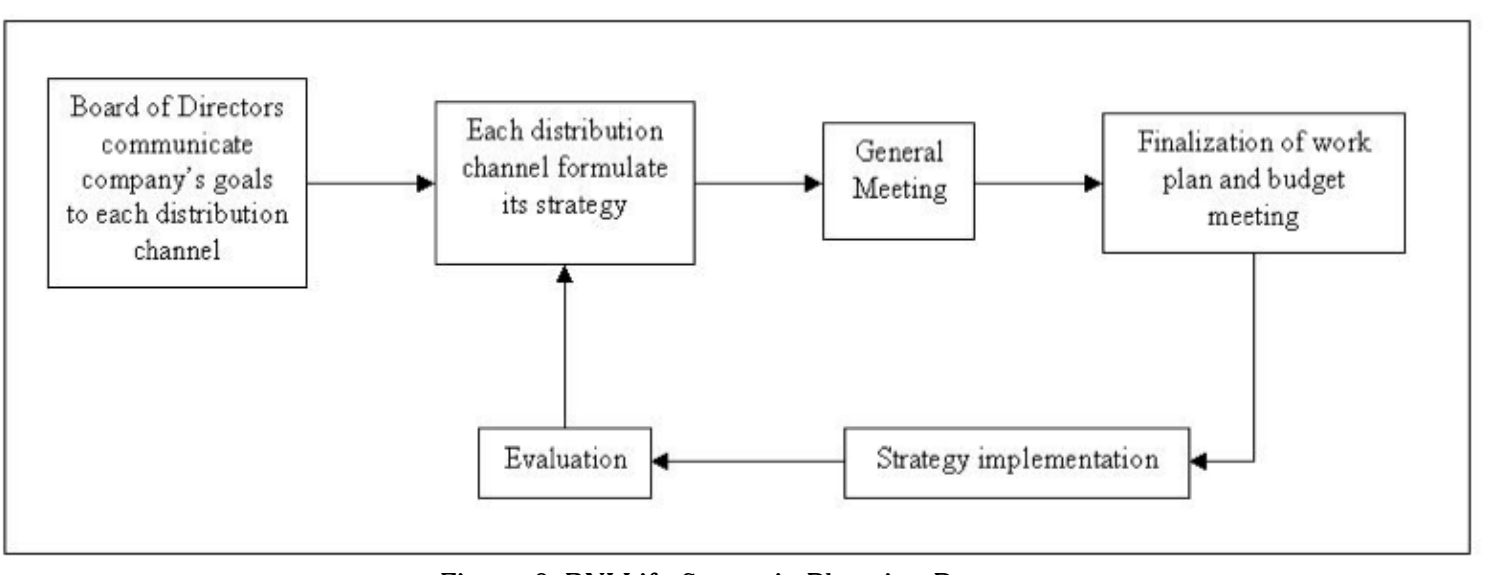

Figure 8. BNI Life Strategic Planning Process

in variety of ways, such as: (1) companies conduct their own research and development function (R\&D); (2) direct involvement in manufacturing; (3) directly investment in absorptive capacity. For example: a company send their personnel for advance technical training; (4) developed through an examination of the cognitive structure that underlie learning, because organization's absorptive capacity will depend on the absorptive capacities of its individual members. Based on the explanation, this study finds that BNI Life through its marketing support and development sub division under marketing division and actuary division, improve its absorptive capacity. Besides, BNI Life also sends its personnel to join the training outside the company. In turbulent environment, the absorptive capacity represents a strong predictor for organizational responsiveness (Welch et al.).

The second generic of dynamics capability is ambidextrousness capability. According to O'Reilly and Tushman (2007) ambidexterity is a fundamental tension at the hearth of a firm's long run survival. This ability refers as doing both exploitation and exploration in organizational learning process at the same time. Generally, ambidexterity requires a coherent alignment of competencies, structures and cultures to engage in exploration, a contrasting congruent alignment focused on exploitation, and a senior leadership team with the cognitive and behavioral flexibility to establish and nurture both (O'Reilly and Tushman, 2007). In the organizational context, organizational ambidexterity defines as the capacity that simultaneously achieves alignment and adaptability at a business unit leve through combination of four behaviors, such as: stretch, discipline, support and trust (Gibson and Birkinshaw, 2004). When the term of ambidexterity conceptualized as above, all more conducive fo sustainable performance. It is because alignment activities lead to the improvement of the short term performance and adaptability activities lead to improving of the long term performance.

In this context, BNI Life has implement the exploitation activities but not yet implement full exploration activities. BNI Life implements exploitation activities through the implementation of new product development, SOP, project reviews, etc. Meanwhile, in exploration activitie BNI Life only half of knowledge acquisition such as provides training and recruitment programs, bechmarking, etc. these findings are supported by March (1991) in his conceptual paper. March (1991) mentioned that exploitation activitie include refinement, choice, production, efficiency, selection, implementation and execution. While exploration activities include search, variation, risk taking, experimentation, play, flexibility, discovery and innovation. The In insurance industry, where the market still growth, is important to have ambidextrous ability to improve its market share and performance. 
In turbulent environment, the last basic capability should possess by a company is continuous morphing. Because in rapid change, complex and unpredictable business environment, competitive advantages tend to be temporary, so the company should try to find out the way to create and renew their competitive advantage. Continuous morphing is profound transformation (Rindova and Kotha, 2001). This includes significant changes in the ranges of products and services offered along with reconfiguration of the resources, capabilities and structured employed to deliver the extend range of products and services. This study finds BNI Life insurance is partly achieving the continuous morphing capability. As mention before, currently BNI Life is still in the process o improvement of its resources and capabilities. BN Life is also doing research and improvement for its products in aims to compete with others products from others companies. In term of technology, BN Life still reconstructs its technology to integrate all information systems to improve its performance in serving the customers. It can be said that the currently change in BNI Life is the first step to the continuous morphing

\section{MANAGERIAL IMPLICATIONS}

Having sustainable competitive advantage has become hard when the company only have competitive parity nature. The company needs to sharpen its capabilities to gain the competitive advantage that could be lead it to sustainable competitive advantages. In a turbulent environment, strategic flexibility becomes one capability that can lead a company to possess the sustainable competitive. It refers to company ability to align its strategy with the busines environment and the ability to modify its strategy. To develop its strategic flexibility capabilities and attain the capabilities are not easy. This study recommended few things the company can do to develop and maintain its strategic flexibility.

More aware of external environment changes. With the respect to all division, all people in BN
Life should be aware of external environment changes. This can help BNI Life as an organization to identify all the uncertain dimension factors to develop its strategy. Through routine environment scan, the company will be able to read, prepare and react to the industry and market change.

Establish condition for both incremental and radical changes. Facing the uncertain, dynamics and complex environment change requires frequent and sometimes radical changes in the company. A company as an organization should establish the condition for encouraging the outcomes. Establish condition for both incremental and radical change will help the company to face the changes and react to the possibility of chaos because of changes. In sort of the environmental turbulence, this study finds that one of radical change can be done by company is change the company's form into organization learning. this also can helps company to develop and improve its absorptive capacity and ambidextrousness.

Using the scenario model as a basis for strategic planning. Scenario is one of primary ingredients of strategic flexibility. Scenario provides managers efficient way to summarize and synthesize the interaction between all related and relevant variable in coherent picture. Scenario role is not for prediction but for anticipate the change. This will help company react fast if one of the uncertain dimensions change.

Considers "real options" in the formulation of firm's strategy. In a volatile and unpredictable environment, real option is not only important for the appraisal of investment project but also in formulating the firm's strategy. Here, Leppard defines real options as a series of techniques for assigning value to the strategic flexibility managers have in the valuation of physical assets or projects (Mitchell Jr, 2007). Grant (2008) noted that from an option point of views strategy is concerning with the creating and managing option. This will helps company to focus on particular strategic decision.
Have someone play devil's advocate. A leader of an organization needs to be keep truly open minded and encourage the people in the organization to voice their view to avoid them from "stuck in too-rigid way" of looking at the world. Having the devil's advocate will helps a leader to achieve this need. Beside that, this person or group can play as a warning alarm for the organization.

Analyze the outcome and apply learning. The stem of flexibility is the ability to learn. The learning ability can increase if the company has many experiences and carefully examining the outcome of its negative result as well as positive result. At this point, it is important for BNI Life to analyze all the outcomes of implement strategy and apply its as a factor for learning process in develop the strategy.

\section{CONCLUSION}

The changing in business environment makes the competitive landscape also changes. In this business environment, companies are facing high competitive competition. Every company is demanded to be creative. They should be creative in their strategies and their operational. This study aims to explore and examine the strategies that implemented by BNI Life Insurance to improve and maintain its performance in hypercompetitive market. This study finds few of points that answer all the questions in problem formulation.

In turbulence environment, BNI Life applies the reactive action to maintain and improve its performance. BNI Life replaces the existing strategy with the new strategy to align with its business environment and compete with its competitors. Seen from the action, BNI Life only implements reactive action and tend not to implement the proactive action. If this occurs continuously BNI Life could be the victim of strategy paradox.

Through its R\&D division BNI Life builds its absorptive capacity and fully implemented. In term of ambidextrousness, BNI Life has not achieved because the exploration activities has not full implemented yet. BNI Life implement is exploitation activities through fully refinement of its organizational, efficiency in term of process to serve customers, select the rightpeople, implemen and execute the right program rewarding, contro system and strategies to improve its performance. For the continuous morphing ability, BNI Life is still in the process of first step to possess continuou morphing in order to examine the competitive advantage of its organization.

To improve and develop its strategic flexibility capabilities, BNI Life is doing sort of actions such as optimalization of research and development division, giving more incentive workshop and training for leader qualities education, implementation of new IT system, etc.

In order to assess the effectiveness of it strategic flexibility, BNI Life does not use specia assessment. They only apply the self-assessmen based on Bapepam LK suggestion, which is based on the government regulations such as: No. 424/KMK.06/2003 about financial health of insurance company and re-insurance company, 423/KMK.06/2003 about inspection of insurance companies, etc.

Based on the explanation, BNI Life exists in hig dynamics and complexity business environment, but still controllable. The implementations of strategic flexibility in term of ex post activities can help BNI Life to maintain and improve it performance but it cannot avoid BNI Life become the victim of strategic paradox. The changing of competition, regulation, technology and trend in the industry encourage BNI Life to posses dynamic capabilities. This study concludes tha only $50 \%$ of the dynamic capabilities or strategic flexibility capabilities possessed by BNI Life. It is because they only possess absorptive capacity, partly of continues morphing and not yet achieve the ambidextrousness. Besides that, the strategic flexibility audit shows BNI Life's flexibility on its 
functional areas at moderate level. In the future, possessing less strategic flexibility capability and less flexible in functional area will lead BNI Life becomes victim of strategy paradox. Because at

one point BNI Life cannot align its strategy with the environment change and it also affect on the company's response toward the change.

\section{REFERENCES}

Aaker, David A., and Brian Mascarenhas. (1984). The need for strategic flexibility. Journal of Business Strategy, 5. 74-82 Ansoff, Igor and Patrick A. Sullivan. (1993). Optimizing profitability in turbulent environments: A formula for strategic success. Long Range Planning, 26,11 - 23

Barney, J. B. (2002). Gaining and sustaining competitive advantage. Upper Saddle River, New Jersey, Prentice Hall. Barney, Jay. (1991). Firm resources and sustained competitive advantage. Journal of Management, 17, 99 - 120

Bitar, Jad. (2003). Strategy in turbulent environment continuous innovation and generic dynamic capabilities. Working Paper Chaire management stratégique international Walter-J, Somers, HEC Montréal

Cohen, Wesley M. and Daniel A. Levinthal. (1990). Absorptive capacity: A new perspective on learning and innovation. Administrative Science Quarterly, 35, 128 - 152

Combe, Ian A., and Gordon E Greenlay. (2004). Capabilities for strategic flexibility: cognitive content framework. European $2,1456-1480$

Copeland, William, Jr., Diane Davies, and Erin Reuss-Hannafin. (2007). Strategic flexibility in Health Plan Industry. Deloitte 作,

Crossan, M. M., Henry W. Lane and Roderick E. White. (1999). An organizational learning framework: from intuition to $2422-537$

Crossan. Mary M. In Iris Berdrow. (2003). Organizational learning and strategic renewal. Strategic Management Journal, 24, $1087-1105$

Cyert, R. M. and James G. March. (1963). A behavioral theory of the firm. Eaglewood Cliffs, New Jersey, USA: Prentice-Hall D’Aveni, Richard A. (1995). Hypercompetitive rivalries. New York, NY: Free Press

Duncan, R. B. (1972). Characteristics of organizational environments and perceived environmental uncertainties. Administrative Science Quarterly, 17, 313

Eisenhard, Kathleen M. and Jeffreyn A. Martin. (2000). Dynamic capabilities: what are they? Strategic Management Journal, $21,1105-1121$

Evans, J. Stuart. (1991). Strategic flexibility for high technology manoeuvres: a conceptual framework. Journal of Management Studies, 28, 69-89

Fellenz, Martin R. (2000). Flexibility in management theory: Toward clarification of an elusive concept. Research Paper, Trinity College Dublin, Ireland

Gibson. C.B., and J. Birkinshaw. (2004). The antecedents, consequences, and mediating role of organizational ambidexterity. Academy of Management Journal, 47, 209 - 226

Hart, A. G. (1937). Anticipations, business planning and the cycle. Quarterly Journal of Economics, 51, 272-293

Hawawini, Gabriel, Venkat Subramanian and Paul Verdin. (2003). Is performance driven by industry-or firm-specific factors? A new look evidence. Strategic Management Journal, 24, 1- 16

Leavy, Brian. (2007). Managing the risks that go with high-impact strategies in uncertain market. Strategy \& Leadership, 35, $43-46$

MacKinnon, W., G. Grant, and D. Cray. (2008). Enterprise information systems and strategic flexibility", proceeding of the $4 l^{t}$ Hawaii International Conference on System Sciences, retrieved from www JFFE con

March, J. G. (1991). Exploration and exploitation in organizational learning. Organizations Science, 2. 71 - 87

O'Reilly, C. A. and Micheal L. Tushman. (2007). Ambidexterity as dynamics capability: Resolving the innovator's dilemma. Research paper. Stanford Graduate School of Business.

Porter, Micheal E. (1980). Competitive strategy: Techniques for analyzing industries and competitors. New York, NY. The Free Press

Porter, Micheal E. (1996). What is strategy?. Harvard Business Review, 74

Raynor, Michael E. (First Edition). (2007). The Strategy Paradox: why committing to success leads to failure and what to do about it. New York. Currency Doubleday Press.

Rindova, Violina P. and Suresh Kotha. (2001). Continuous morphing competing through dynamic capabilities, forms and function. Academy of Management Journal, 44, 1263-1280

Rumelt, Richard. P. (1991). How much does industry matter?. Strategic Management Journal, 12,167 - 185 Sanchez, Ron. (1995). Strategic flexibility in product competition. Strategic Management Journal, 16, 135-195

Sanchez, Ron. (1997). Preparing for an uncertain future: Managing organization for strategic flexibility. International Studies of Management and Organization, 27, 71 - 94

SAP Solution. (2007). Respond quickly to changing markets. SAP Solutions for Small Business and Mid Companies, retrieved from http://www.sap.com

imizu, K. and Micheal, A. Hitt. (2004). Strategic flexibility: Organization preparedness to reverse ineffective strategic decisions. Academy of Management Executive, 18, 44-59

Sinkula James M. (1994). Market information processing and organizational learning. Journal of Marketing, 58, 35 - 45 Stieglitz, Nils. and Klause Heine. (2007). Innovations and the role of complementarities in a strategic theory of the firm Strategic Management Journal. 28, 1-1

Stigler, George, J. (1939). Production and distribution in short run. Journal of Political Economy, 47, 305-327 Sugiyono. (2011) (2nd edition). Metode Penelitian Kombinasi (Mixed Method). Alfabeta Press. Bandung. Indonesia Teece, David J., Gary Pisano and Amy Shuen. (1997). Dynamic capabilities and strategic management. Strategic Managemen Journal, 18, $509-533$

Tushman, Micheal L. and Charles A. O'Reilly III. (1996). Ambidextrous organization: Managing evolutionary and revolutionary change. California Management Review, 38, 8- 30

Upton, David M. (1994). The management of manufacturing flexibility. California Management Review, 37,72-89

Volberda, Henk, W. (1998). Building the flexible firm; how to remain competitive, New York, NY. Oxford University Press

Weerdt, Niels Van Der, Ernst Verwaal, and Henk Volberda. (2009). A diametric contingency model of firm size and strategic flexibility, Research paper, RSM Erasmus University, Netherlands 